\title{
De waarheid, absoluutheid en eigenheid van het christendom volgens Nederlandse protestanten ${ }^{\star}$
}

\author{
J.A.B. Jongeneel
}

\begin{abstract}
This article describes and analyses the views of $20^{\text {th }}$ Dutch Protestant scholars of religious studies, systematic theology and missiology on 'the absoluteness of Christianity/the revelation of God in Jesus Christ', and their response to Western relativism rooted in the Enlightenment. Previous adherence to the Augustinian concept of Christianity as 'the true religion,' was exchanged for new ideas and positions that took them back to the essentials behind the concept of 'the absoluteness of Christianity;' to rethinking 'absoluteness;' 'the non-absoluteness of Christianity;' and alternative terms such as 'finality,' 'originality,' and 'normativity.' The concept of 'the absoluteness of Christianity' may have disappeared but elements thereof survive in new forms.
\end{abstract}

In de afgelopen vijf eeuwen is het protestantisme uitgegroeid tot ongeveer tien procent van de wereldbevolking. Vooral rooms-katholieken (sinds de zestiende eeuw) en aanhangers van de traditionele godsdiensten (sinds de achttiende eeuw) zijn protestants geworden. Doch in Korea werden grote groepen boeddhisten protestants christen. Door emigratie en zending heeft het Nederlandse protestantisme een substantiële bijdrage geleverd aan deze wereldwijde ontwikkeling.

Vijf eeuwen protestantisme betekent ook vijf eeuwen zelfreflectie en zelfprofilering in West en Oost. In de twintigste eeuw gingen Nederlandse protestanten de term 'de absoluutheid van het christendom' gebruiken om zichzelf versus het relativisme - te profileren. Daarvoor en daarnaast bedienden zij zich van de eeuwenoude term 'de ware godsdienst'. In het jongste verleden zijn zij gestopt met het nog langer benutten van de term 'de absoluutheid van het christendom' in de titels van hun publicaties. Nu zijn zij op zoek naar alternatieven om het wezen van het christendom offensief en defensief te vertolken.

$\mathrm{Na}$ in het kort gewezen te hebben op het gebruik van de term 'ware godsdienst' en het ontstaan van het relativisme in de westerse cultuur schetst deze bijdrage uitvoerig de receptiegeschiedenis van het begrip 'de absoluutheid van het christendom/de openbaring van God in Jezus Christus' in het Nederlandse protestantisme. Deze bijdrage wordt afgesloten met een summiere bespreking van enkele richtingen waarin Nederlandse protestanten in 
het jongste verleden zijn gaan denken over de claims van het christendom en de niet-christelijke godsdiensten. Deze recente gedachten, gevormd in voortdurend gesprek met het wereldprotestantisme, kunnen wellicht onder het kopje 'eigenheid' worden samengevat.

\section{Het christendom als de ware godsdienst en de opkomst van het relativisme}

Sedert Augustinus is de westerse christenheid gewoon zichzelf te zien als 'de ware godsdienst (religio vera).' ${ }^{\prime}$ Op protestants erf hebben de reformatoren zich bij deze opvatting aangesloten. De Nederlandse Geloofsbelijdenis (1561) wil "weren en uitroeien alle afgoderij en valse godsdienst, en het rijk van de Antichrist te gronde richten" (artikel 16). Hier te lande profileerden Hugo de Groot, Gijsbertus Voetius en Petrus Hofstede de Groot het (protestantse) christendom als 'de ware godsdienst.'2 In tegenstelling tot de Groningse godsdienstwijsgeer Harmen de Vos trok de Amsterdamse godsdiensthistoricus C. Jouco Bleeker deze lijn door naar Hendrik Kraemer. ${ }^{3}$

De wijsbegeerte van de Verlichting relativeerde het christendom. Kerk en theologie reageerden op deze aanval met de verdediging van de christelijke waarheden. Het Engelse protestantisme initieerde apologetische lezingen: Boyle lectures, Warburton lectures en Bampton lectures. ${ }^{4}$ In het begin van de negentiende eeuw riepen Duitse idealisten het relativisme een halt toe door te gaan spreken over 'die Absolutheit des Christentums. ${ }^{5} \mathrm{Na}$ de publicatie van Ernst Troeltsch, Die Absolutheit des Christentums und die Religionsgeschichte (1902, herzien in 1912) nam deze term een hoge vlucht. ${ }^{6}$ Voorzover bekend waren er voordien geen Nederlandse protestanten die een verhandeling schreven over 'de absoluutheid van het christendom.' Troeltsch inspireerde hen om dit te gaan doen.

1 Augustinus, De religione vera (ca. 390).

2 Jan A.B. Jongeneel, Nederlandse zendingsgeschiedenis: Ontmoeting van protestantse christenen met andere godsdiensten en geloven (1601-1917) (Zoetermeer 2015), 33, 36, 168

3 Harmen de Vos, Het christendom en de andere godsdiensten (Nijkerk 1962), 25-47. C. Jouco Bleeker, Christus in het moderne Athene: Confrontatie van het christendom met de moderne cultuur en de niet-christelijke godsdiensten (Wassenaar 1967), 81-93.

4 Jan A.B. Jongeneel, Het redelijke geloof in Jezus Christus: Een studie over de wijsbegeerte van de Verlichting (Wageningen 1971), 215.

5 Joseph Klein, “Absolutheit des Christentums," in: Die Religion in Geschichte und Gegenwart, I (Túbingen 1957), 76-78.

6 Ernst Troeltsch, Die Absolutheit des Christentums und die Religionsgeschichte, und zwei Schriften zur Theologie (München-Hamburg 1969). 
Aan het einde van de negentiende eeuw kwam een andersoortige relativering van het christendom als 'de ware godsdienst' tot stand. In 1893 werd te Chicago een Wereldparlement der Godsdiensten gehouden waar voor het eerst in de wereldgeschiedenis aanhangers van alle godsdiensten op voet van gelijkheid bijeenkwamen. ${ }^{7}$ In Nederland protesteerde de Utrechtse hoogleraar en zendingsman Josué J.P. Valeton fel tegen deze relativering van het christendom. ${ }^{8}$ In breder verband keerde de te Edinburgh gehouden wereldzendingsconferentie (1910) zich tegen het in het Westen ontstane relativisme dat hindoeïstische, boeddhistische en islamitische zendelingen deed besluiten in Noord-Amerika en Europa eigen missionair werk te gaan doen. Uitgaande van het christendom als 'de ware godsdienst' nam deze conferentie het wachtwoord van de Student Volunteer Movement for Foreign Missions over: 'The evangelization of the world in this generation.'9

\section{De absoluutheid van het christendom}

Omdat de publicatie van Troeltsch aan de wieg van de Nederlandse gedachtenvorming over 'de absoluutheid van het christendom' staat, wordt eerst aandacht besteed aan dit nooit in het Nederlands vertaalde werk. Daarna wordt ingegaan op de Nederlandse bijdragen over dit onderwerp, die geleverd werden door (1) godsdienstwetenschappers, (2) systematisch theologen en (3) missiologen met missionaire ervaring in Indonesië. Deze drie categorieën denkers plaatsten de genoemde thematiek in het kader van de door de Verlichting geïnitieerde veranderingen in de westerse cultuur, maar de laatstgenoemde categorie schrijvers stelde haar bovendien in het kader van de op 'het zendingsveld' vormgegeven missionaire ontmoeting met andere godsdiensten. Het artikel van de Amsterdamse hoogleraar Pierre D. Chantepie de la Saussaye in Eltheto (1913) schijnt de eerste bijdrage over het onderhavige thema op Nederlandse bodem te zijn, en een publicatie van Johannes Verkuyl uit 1971 de laatste.

\subsection{Ernst Troeltsch: relatieve absoluutheid van het christendom}

Ernst Troeltsch (1865-1923) was hoogleraar in Heidelberg en Berlijn. Als systematisch theoloog en godsdienstwetenschapper hield hij zich intensief bezig

7 Marcus Braybrooke, Pilgrimage of hope: One hundred years of global interfaith dialogue (Londen 1992), 5-42.

8 Josué J.P. Valeton, "Het wereld-godsdiensten-congres en de zending", in: Berichten aangaande de uitbreiding van Gods koninkrijk op aarde, 48/1-2 (1894), 22-25. Vgl. Jongeneel, Nederlandse zendingsgeschiedenis, 177-79, 201.

9 Arthur P. Johnston, World evangelism and the Word of God (Minnesota 1974), 63. Vgl. Jongeneel, Nederlandse zendingsgeschiedenis, 293. 
met het historisme in de westerse cultuur. In Die Absolutheit des Christentums und die Religionsgeschichte (1902) besprak hij het christendom als religie te midden van de andere religies. Hij besteedde meer aandacht aan die godsdiensten in het algemeen dan aan concrete godsdiensten. In het voorbijgaan noemde hij de Boeddha en Mohammed, maar nergens wees hij op swami Vivekanda, die een grote rol gespeeld had op het Wereldparlement der Godsdiensten te Chicago (1893). In wezen is zijn publicatie een puur westers boek, waarin de veelzijdige ervaring van westerse zendelingen met andere godsdiensten in de niet-westerse wereld niet verdisconteerd is. In ander verband liet Troeltsch zich wel uit over zending. Persoonlijk beschouwde hij haar niet als arbeid ter bekering en redding van 'heidenen,' maar als verspreiding van de in het christendom gewortelde westerse cultuur: "die Ausbreitung der religiösen Ideenwelt Europas und Amerikas im engen Zusammenhang mit der Ausbreitung der Europäischen Einfluszsphäre."10

In Die Absolutheit des Christentums und die Religionsgeschichte plaatste Troeltsch de problematiek van 'de absoluutheid' in het kader van de 'nieuwe tijd,' die alle verschijnselen, dus ook alle godsdiensten, historisch verklaren wil. Hij beschouwde godsdiensten als historische werkelijkheden, maar gaf ze uiteindelijk niet prijs aan de relativiteit. Omdat zij verwijzen naar bovenhistorische normen en waarden, sprak hij over 'de absoluutheid van de godsdiensten' in het algemeen. ${ }^{11}$ Daar de kracht en diepte van de christelijke normen en waarden die van andere godsdiensten overtreffen, presenteerde hij, in vrije aansluiting bij Georg W.F. Hegel (1770-1831), het christendom als de hoogste godsdienst tot nu toe. Volgens Troeltsch vergt het gangbaar geworden historische denken "eine Umdenkung des ganzen religiösen Bestandes, aber sie lösen den christlichen Personalismus und die Zuversicht zu seiner einzig groszen Einstellung auf das Absolute nicht auf."12

Hendrik Kraemer vatte de visie van Troeltsch op het christendom samen in twee woorden: "relatieve absoluutheid."13 Jacob Klapwijk is de enige Nederlander die specifiek studie maakte van het denken van Troeltsch over 'de absoluutheid van het christendom.' Hieraan wijdde hij een artikel in het Gereformeerd Theologisch Tijdschrift en een paragraaf in zijn aan de VU ver-

10 Ernst Troeltsch, "Die Mission in der modernen Welt" (1906), in: Ernst Troeltsch, Gesammelte Schriften, II (Tübingen 1913), 796-97. Vgl. Johannes C. Hoekendijk, Kerk en volk in de Duitse zendingswetenschap (Amsterdam 1948), 81.

11 Troeltsch, Die Absolutheit des Christentums und die Religionsgeschichte, 111.

12 Ibid., 131.

13 Hendrik Kraemer, The Christian message in a non-Christian world (Bangalore 2009), 109. De oorspronkelijke uitgave verscheen in 1938. 
dedigde wijsgerige proefschrift. ${ }^{14}$ In genoemd artikel beschreef hij het standpunt van Troeltsch niet dialectisch als 'relatieve absoluutheid' (Kraemer), maar historisch/eschatologisch: bij Troeltsch rijst het christendom op "als hoogte- en convergentiepunt van heel de godsdienstontwikkeling, doch niet meer als mogelijk eindpunt. Het absoute eindpunt moet ergens in het hiernamaals liggen."15

\subsection{Godsdienstwetenschappelijk perspectief: de absoluutheid van alle godsdiensten}

Vijf Nederlandse godsdienstwetenschappers schreven over de absoluutheid van het christendom. In chronologische volgorde: Pierre D. Chantepie de la Saussaye (1848-1920), William Brede Kristensen (1867-1953), Hendrik Kraemer (1888-1965), Klaas A.H. Hidding (1902-86) en Dirk J. Hoens (19202003). In deze paragraaf wordt ingegaan op Chantepie, Kristensen en Hidding. Hoewel Kraemer te Leiden Kristensen opvolgde, wordt hij ingedeeld bij de missiologen. Daar hoort trouwens ook Hoens thuis, die weliswaar geen overzeese zendingservaring had, maar wel voluit missionair dacht. In zijn afscheidscollege deed hij de volgende met Kraemer verwante uitspraak: "Als God een levende Heer is en wij levende mensen zijn, zullen we meer oog dienen te hebben voor de dynamiek der religies. Ten slotte dienen christenen te bedenken dat het Evangelie hun als een opdracht is toevertrouwd en niet als een bezit, waarover zij kunnen beschikken. Van absoluutheid van het christendom, een mengeling van het Evangelie en menselijke inzichten en praktijken, kan geen sprake zijn. Alleen God, zoals Hij zich in Jezus Christus geopenbaard heeft, is absoluut in zijn dynamische liefde."16

Op de tiende zomerconferentie van de Nederlandse Christen Studenten Vereniging (NCSV) te Nunspeet (1913) hield Chantepie, schrijver van het tweedelige handboek Lehrbuch der Religionsgeschichte (1887-89) en grondlegger van de ethische theologie, een voordracht over 'de absoluutheid des christendoms.' Dit onderwerp had hij niet zelf bedacht, maar was hem opgegeven door de NCSV. In zijn voordracht noemde hij Troeltsch expliciet, maar ging hij niet op diens denken in. Wel kan zijn betoog gelezen worden als een doorlopend gesprek met Troeltsch. Na erop gewezen te hebben dat het woord

14 Jacob Klapwijk, Tussen historisme en relativisme: Een studie over de dynamiek van het historisme en de wijsgerige ontwikkelingsgang van Ernst Troeltsch (Assen 1970), 131-47: "De absoluutheid van het christendom en het relativisme."

15 Jacob Klapwijk, "De absoluutheid van het christendom en zijn historische en sociologische gebondenheid (Ernst Troeltsch)," in: Gereformeerd Theologisch Tijdschrift, 70 (1970), 25.

16 Dirk J. Hoens, Dr. Friso Melzer (Utrecht 1983), 10. 
'absoluut' niet aan het godsdienstige spraakgebruik ontleend is, gaf Chantepie aan dat de menselijke geest 'het absolute' niet kan missen. Hij stelde dat iedere gelovige christen zal beamen dat de eeuwig leven brengende verschijning van Jezus Christus op aarde voor mij absoluut is. Volgens hem is daarmee niet gezegd dat het christendom als godsdienst voor iedereen absoluut is. Hij beschouwde het christendom, de godsdienst die vanaf zijn ontstaan "allerlei levensvormen en denkbeelden uit de heidenwereld overgenomen heeft," niet als absoluut, maar het persoonlijke geloof wel. Immers, dat "erkent, neemt aan, kiest wat God ons te zien geeft en te ervaren in Jezus Christus. Dit is het absolute, het bovenaardse, het eeuwige tot en in ons gebracht." Bijgevolg keerde Chantepie zich tegen het inprenten van 'het christendom' in de nietwesterse wereld, maar toonde hij respect voor mensen als de bijbelvertaler Nicolaus Adriani (1856-1926) op Midden-Sulawesi, die geen drager was van 'een uiterlijk christendom,' maar een oprecht gelovige christen die aan 'heidenen' het vernieuwende evangelie van Jezus Christus bediende en zo ter plaatse 'absolute kracht' bracht. ${ }^{17}$

Kristensen stamde uit het lutherse Noorwegen. Zijn eerste vrouw was Noors, zijn tweede vrouw Nederlands. In 1913 verwierf hij de Nederlandse nationaliteit. Tijdens zijn professoraat in Leiden (1901-1937) publiceerde hij een artikel over 'de absoluutheid van het christendom,' dat eerst in Eltheto verscheen (1928) en daarna in een bundel van godsdiensthistorische studies (1954). Kristensen verwees niet naar Troeltsch en Chantepie, maar wel naar Hegel. Hij maakte onderscheid tussen de absolute en relatieve werkelijkheid en vroeg zich af of het christendom tot de absolute werkelijkheid behoort. Hij constateerde dat over 'de absoluutheid van het christendom' uiteenlopende opvattingen bestaan en dat een rationele instelling leidt tot de conclusie van 'het relatieve karakter van deze absoluutheid.' Desalniettemin blijven overtuigde christenen spreken over 'de absoluutheid' van hun godsdienst. Zij attenderen op 'de heroën van het christendom,' over wie gezegd kan worden: "De overwinning op de wereld is de werkelijkheid der absoluutheid." Het historisch onderzoek kan nooit de absoluutheid van het christendom aantonen of waarschijnlijk maken. Het kan wel het unieke karakter van elke godsdienst verhelderen. Kristensen trok de volgende conclusies. Ten eerste, christenen moeten rekening houden met 'de absoluutheid van andere godsdiensten,' die immers ook 'unieke verschijnselen' zijn. Ten tweede, alleen gelovigen kunnen spreken over de absoluutheid van hun geloof. "De volstrekte zekerheid die

17 Pierre D. Chantepie de la Saussaye, "De absoluutheid des christendoms," in: Studenten Weekblad Eltheto: Orgaan van de N.C.S.V., 68 (1913), 5-6. 
het geloof van de christen kenmerkt - dus de werkelijke absoluutheid van het christendom - heeft geen vergelijking met andere godsdiensten nodig om zich te handhaven." 18 In het accentueren van het persoonlijke geloof toont Kristensen gelijkenis met Chantepie. Maar in tegenstelling tot deze geleerde bracht Kristensen de zending niet ter sprake.

Hidding had een sterke band met Indonesië. Hij promoveerde bij de islamoloog Christiaan Snouck Hurgronje op een proefschrift over rijst in de Soendanese godsdienst en in de Bijbel (1929) en werd daarna directeur van het overheidsbureau voor lectuurverspreiding te Batavia, nu Jakarta. Tijdens zijn hoogleraarschap te Leiden (1948-1972) publiceerde hij zijn in 1958 op de moderne theologenvergadering te Amsterdam gehouden lezing over 'de absoluutheid der godsdiensten en het christendom.' Hierin keerde hij zich resoluut tegen zijn voorganger Kraemer, maar sprak hij met respect over Adriani op Midden-Sulawesi die "de ernst van het heidendom" onderkende, en over Kristensen die "tot de slotsom kwam dat alle godsdiensten voor de gelovigen een absolute betekenis hebben." Hidding deelde de godsdiensten in naturalistische en historische godsdiensten in. Volgens hem werd de eerstgenoemde categorie gekenmerkt door 'de absolute kosmische macht,' de laatstgenoemde categorie (boeddhisme, jodendom en islam) daarentegen door 'het recht van de absolute geest.' Hij stelde vervolgens dat het christendom een geheel eigen positie in de wereld der godsdiensten inneemt: het draagt 'de absolute liefde' uit. Immers, christenen zijn ervan overtuigd dat het mysterie niet geopenbaard wordt in de heilige kosmische macht (naturalistische godsdiensten), en ook niet in het geestelijk recht van God als Schepper (jodendom en islam), maar uitsluitend in "de Persoon [Jezus Christus] die [door zijn opofferende liefde] in absolute zin de naaste is." 19 Deze liefde onderstelt 'vrijheid in absolute zin.' Volgens Hidding wordt het christendom zo bepaald door 'het volstrekte primaat van de Persoon en van de vrijheid der liefde.' Hij keerde zich tegen de deformatie van het christendom die ontstaat wanneer christenen zich niet alleen op 'liefde,' maar ook op 'macht' en/of 'recht' baseren - en dat was volgens hem soms meer regel dan uitzondering.

Alle drie besproken godsdienstwetenschappers beperkten 'absoluutheid' niet tot het christendom. $\mathrm{Zij}$ deelden verder de opvatting dat godsdiensten alleen 'absoluut' zijn voor hun eigen aanhangers. Alleen Hidding deed een

18 William Brede Kristensen, "De absoluutheid van het christendom" (1928), in: William Brede Kristensen, Symbool en werkelijkheid: Een bundel godsdiensthistorische studiën (Arnhem 1954), 94.

19 Klaas A.H. Hidding, "De absoluutheid der godsdiensten en het christendom," in: Nieuw Theologisch Tijdschrift, 13 (1958/59), 90, 95. 
poging 'de absoluutheid van het christendom' ook op bovenpersoonlijk vlak gestalte te geven. Hij profileerde het christendom als de godsdienst van 'de absolute liefde (agape).' Hij verwierp niet alleen de dialectische theologie van Karl Barth en Hendrik Kraemer, maar beschouwde ook het overgeleverde christendom, met zijn dogmatisme, legalisme en 'de verabsolutering van wat men ten onrechte als het eigene aanziet,' als 'ver onder de maat.'

\subsection{Systematisch-theologisch perspectief: zuiver houden van het kerygma en de finaliteit van Jezus Christus}

In zijn vierdelige Gereformeerde dogmatiek (tweede herziene druk 1906-11) definieerde Herman Bavinck God als "het volstrekt onafhankelijke, enige, absolute wezen." ${ }^{20}$ Hij deed dit zonder in te gaan op de visie van Troeltsch. Wel trad hij in 1913 aan de VU op als de promotor van Barend B. Keet (18851974), die hier te lande de eerste aan Troeltsch gewijde dissertatie verdedigde. ${ }^{21}$ Aangezien Keet Zuid-Afrikaan was en zijn studie geen sporen naliet in de Nederlandse literatuur, wordt dit werk hier buiten beschouwing gelaten.

In de twintigste eeuw schijnen systematisch theologen meer over 'de absoluutheid van het christendom' geschreven te hebben dan hun godsdienstwetenschappelijke collegae. In elk geval spraken de volgende twee hervormde kerkelijk hoogleraren zich duidelijk uit: Frederik W.A. Korff (1887-1942) en Hendrikus Berkhof (1914-95). Bij anderen treft men slechts losse opmerkingen aan. Om een voorbeeld hiervan te geven, Kornelis H. Miskotte (18941976), te Leiden hervormd kerkelijk hoogleraar in de periode tussen Korff en Berkhof, gebruikte het woord 'absoluut(heid)' verschillende keren in zijn boek over het Oude Testament: Als de goden zwijgen (1956).22

Korff thematiseerde het ter discussie staande onderwerp niet in zijn tweedelige hoofdwerk Christologie (tweede druk 1942), maar wel in zijn postuum uitgegeven college-manuscript Het christelijk geloof en de niet-christelijke godsdiensten (1946). Hierin ging hij uitvoerig in op Troeltsch die, evolutionistisch denkend, een rangorde in de godsdiensten aanbracht en het christendom boven aan de lijst plaatste, met de kanttekening dat het tot $n u$ toe de hoogste godsdienstvorm was. Korff vond dat Troeltsch als godsdienstwijsgeer volledig gelijk had. Maar hijzelf kon, als systematisch theoloog, geen genoegen nemen met voorlopigheid. Een christen die het kerygma zuiver wil houden en zending wil bedrijven, is niet gediend met 'de constructie van de absoluutheid van

20 Herman Bavinck, Gereformeerde dogmatiek (Kampen 1967 ), II, 93.

21 Barend B. Keet, De theologie van Ernst Troeltsch (Amsterdam 1913).

22 Kornelis H. Miskotte, Wenn die Götter schweigen: Vom Sinn des Alten Testaments (München 1963), 47, 80, 104, 396. 
het christendom.' Korff gaf deze term weloverwogen prijs: "Het christendom als in de wereld zich openbarende religie is allerminst 'absoluut,' maar veeleer een uiterst gebrekkig en relatief verschijnsel." 23 Ook gaf hij aan dit begrip niet te willen omvormen tot 'de absoluutheid van Christus.' Volgens hem leidde een dergelijk aangepast vocabulaire alleen maar tot misverstand.

Het systematische denken van Berkhof ontwikkelde zich in een andere context dan dat van Korff. Evenmin als Korff in zijn hoofdwerk Christologie gedaan had, gaf Berkhof zijn mening in zijn hoofdwerk Christelijk geloof (1973). Hij sprak zich uit in een in oecumenisch verband gehouden referaat. Op de vierde assemblee van de Wereldraad van Kerken te Uppsala (1968) behandelde hij 'the finality of Jesus Christ,' een formulering die in de Wereldraad gangbaar was vanaf de derde assemblee te New Delhi (1961). ${ }^{24}$ In het Nederlands verscheen deze bijdrage onder de titel 'de absoluutheid van Jezus Christus.' Berkhof gebruikt de term 'absoluutheid van het christendom' niet, maar spreekt over 'de absoluutheid van de (gekruisigde en opgestane) Jezus Christus.' Verder wisselt hij het gebruik van de term 'absoluutheid' af met begrippen als 'uniekheid' en 'exclusiviteit.' Berkhof wijst eerst op 'de opstanding van Jezus Christus uit de doden' als de basis voor de belijdenis van zijn absoluutheid. Vervolgens bespreekt hij de nog altijd verborgen 'alomvattendheid' van diens heerschappij. Ten slotte noemt hij drie toepassingen van deze absoluutheid die hij van groot belang acht voor de ontwikkeling van de wereldwijde oecumene: 1 . de zoektocht naar het 'humanum,' 2. het verstaan van de tekenen der tijden, en 3. de verwachting van de toekomst. De Heilige Geest zorgt er volgens hem constant voor dat de absoluutheid van Jezus Christus doorwerkt in de tijd en zo uiteindelijk tot vervulling komt. De kernzin uit het betoog van Berkhof luidt: "Wij kunnen de absoluutheid van Christus niet onderscheiden, als de Geest onze ogen niet opent. Onze belijdenis van zijn absoluutheid kan niet steunen op strikt verstandelijke argumenten. In een wereld die niet in de absoluutheid van Jezus kan geloven, staat deze uiteindelijk weerloos." 25

23 Frederik W.A. Korff, Het christelijke geloof en de niet-christelijke godsdiensten (Amsterdam 1946), 38.

24 World Council of Churches, The finality of Jesus Christ in the age of universal history (Geneve 1962). Vgl. J.E. Lesslie Newbigin, The finality of Christ (London 1969). Deze bijdrage van Newbigin werd in 2009 herdrukt in de USA.

25 Hendrikus Berkhof, "De absoluutheid van Jezus Christus" (1968), in: Ellen Flesseman-van Leer e.a. (red.), Bruggen en bruggenhoofden: Een keuze uit de artikelen van prof.dr. $H$. Berkhof ... (Nijkerk 1981), 79-80. 
Op het diepste vlak waren Korff en Berkhof het met elkaar eens: geen concessies doen aan het eigentijdse relativisme. Om de bediening van het evangelie zuiver te houden wilde Korff de term 'absoluutheid' afstoten. Berkhof wilde de term 'absoluutheid van het christendom' eveneens laten varen, maar vond het gebruik van het begrip 'de absoluutheid van Jezus Christus' niet bezwaarlijk. Hij gebruikte ook alternatieve formuleringen. Hij liet zich inspireren door de oecumenische beweging, die aan de term 'finality/doelgerichtheid' de voorkeur gaf omdat deze dichter bij het vocabulaire van het Nieuwe Testament staat dan de term 'absoluutheid.'

\subsection{Missiologisch perspectief: confrontatie van het evangelie met de absoluutheden van andere godsdiensten}

Nederlandse missiologen schreven uitvoeriger over de absoluutheid van het christendom dan de godsdienstwetenschappers en de systematisch theologen. De volgende vier personen met Indonesië-ervaring traden op de voorgrond: Hendrik Kraemer (1888-1865), Johan H. Bavinck (1895-1964), Johannes Verkuyl (1908-2001) en Arend Th. van Leeuwen (1918-1993). Drie van de vier genoemden publiceerden een monografie over dit thema.

In Godsdienst, godsdiensten en het christelijk geloof (1958) besteedde de hervormde lekentheoloog Kraemer meer aandacht aan 'de absoluutheid van het christendom' dan in zijn opus magnum The Christian message in a nonChristian world (1938). Hij onderschreef daarin de kritiek van Korff op Troeltsch, maar gaf de term 'absoluutheid' niet prijs. Hij verklaarde dat "het christelijk geloof absoluut is (om dat stuntelige woord nu nog maar eens te gebruiken). Of beter nog: dat de openbaring van Christus dit is."26 In Waarom nu juist het christendom? (1960) ging hij dieper op de materie in. Hij begon met te wijzen op het standpunt van het relativisme: "Het enig absolute is eigenlijk dat er niets absoluut is." 27 In het slothoofdstuk, getiteld 'Is het christendom absoluut?,' gaf hij een klip-en-klaar antwoord: het christendom - een vermenging van goed en kwaad, waarheid en dwaling - is niet absoluut, maar de openbaring van God in Jezus Christus is dat wel. Deze is "absoluut in de zin van onwrikbaar, vast en betrouwbaar. Daar is de maatstaf der waarheid." 28

Nadat de gereformeerde zendingstheoloog Bavinck in Horizon gevraagd had naar de absoluutheid van het christendom (1934/35), gaf hij bij de in 1894 opgerichte Javasche Boekhandel uit: De absoluutheid van het christen-

26 Hendrik Kraemer, Godsdienst, godsdiensten en het christelijk geloof (Nijkerk 1958), 58.

27 Hendrik Kraemer, Waarom nu juist het christendom? (Nijkerk 1960), 32.

28 Ibid., 107. 
dom. ${ }^{29}$ Deze waarschijnlijk vlak voor de Tweede Wereldoorlog verschenen uitgave analyseerde de bezwaren van de godsdiensthistorische school (Troeltsch) en van de psychologie tegen de absoluutheid van het christendom. Hij vond dat deze disciplines "de werkelijkheid van het Eeuwige, van God, principieel miskennen." In plaats van deze disciplines te volgen en dan uit te komen bij een volslagen loochening van de absoluutheid van het christendom, bleef hij, omwille van het evangelie en vooral Jezus Christus, hieraan vasthouden. Wanneer mensen 'nee' zeggen tegen Jezus Christus en het evangelie, dan verstaan zij het christendom "als een waanzinnige fantasie van een overspannen geest. En zodra u er 'ja' tegen zegt, dan voelt $\mathrm{u}$ dat het absoluut is. [...] Het christendom eist de absolute onderwerping van heel uw zijn en heel uw leven, en het heeft alleen het recht dat van u te eisen, wanneer $u$ het als het Absolute, het Eeuwige aanvaardt en belijdt." ${ }^{30} \mathrm{Na}$ de Tweede Wereldoorlog schijnt Bavinck de term 'absoluutheid' te mijden. In elk geval komt deze niet meer voor in de titels van zijn publicaties. Zijn boek Religieus besef en christelijk geloof (1949) eindigt hij 'absoluut,' zonder het woord 'absoluut' te gebruiken. Hierin omschrijft hij zendingswerk als " ja-zeggen op dat oneindige, ondoorgrondelijke werk van Gods barmhartigheid [...]. Het is nooit jazeggen op de mens, maar het is altijd ja-zeggen op God, op Gods werk, op Gods barmhartigheid." 31

Evenals zijn leermeester Kraemer gaf Verkuyl zijn mening vóór en na de Tweede Wereldoorlog. In De absoluutheid van Gods openbaring in Christus (1938) kritiseert hij Troeltsch en concludeert hij dat "hoe langer men bezig is met zich in te leven in de niet-christelijke godsdiensten, des te meer dringt zich de absoluutheid van Gods openbaring in Jezus Christus aan ons op." 32 $\mathrm{Na}$ de oorlog herschreef Verkuyl dit werk en gaf hij het een nieuwe titel: Zijn alle godsdiensten gelijk? (vierde druk 1981). Hij wees erop dat de reeds genoemde publicatie van de Wereldraad van Kerken, The finality of Jesus Christ in the age of universal history (1962), mensen niet ervan weerhoudt "het absoluut, uniek, finaal en beslissend karakter van Gods openbaring in Jezus Christus" te weerspreken. ${ }^{33}$ Hij ging nu dieper in op de kritiek van

29 Johan H. Bavinck, "Is het christendom absoluut?," in: Horizon, 1 (1934/35), 265-72.

30 Johan H. Bavinck, De absoluutheid van het christendom (Bandoeng z.j.), 15.

31 Johan H. Bavinck, Religieus besef en christelijk geloof (Kampen 1949), 191.

32 Johannes Verkuyl, De absoluutheid van Gods openbaring in Christus ('s-Gravenhage 1938), 51.

33 Johannes Verkuyl, Zijn alle godsdiensten gelijk? Geheel herziene en vermeerderde vierde druk (Kampen 1981), 17-18. Hiervan verscheen een Indonesische vertaling: Samakah semua agama? (Djakarta 1965). 
Troeltsch, het Wereldparlement der Godsdiensten (Chicago 1893) en de voorstanders van het godsdienstig pluralisme. Tegelijkertijd preciseerde hij zijn standpunt. Hij sprak opnieuw over "de absoluutheid en het beslissende van Gods openbaring in Jezus Christus," maar onderstreepte nu voor het eerst "de absolute en voor alle volkeren beslissende aanspraken van Jezus" zelf. ${ }^{34}$ Achter het getuigenis van de christenheid ligt het funderend getuigenis van Jezus over zichzelf en zijn werk.

Evenmin als Chantepie was Arend Th. van Leeuwen, de enige bij Kraemer gepromoveerde theoloog, op de gedachte gekomen te spreken over 'de absoluutheid van het christendom.' Hij deed dit uiteindelijk op verzoek van de conferentieleiding in De Klencke te Oosterhesselen in Drenthe. Hij analyseerde eerst het denken van Hegel en Troeltsch over absoluutheid, maakte vervolgens dankbaar gebruik van de reflecties van Korff en vroeg ten slotte aandacht voor "de absoluutheid van de islam en het hindoeïsme." 35 In het afsluitende gedeelte kruiste Van Leeuwen niet de degens met zijn leermeester Kraemer, maar sloot hij zich aan bij hun gezamenlijke leermeester Karl Barth. In zijn Kirchliche Dogmatik besprak de laatstgenoemde de 'ware godsdienst.' Hij relativeerde toen het christendom door op te merken dat dit als openbaringsgodsdienst gebonden is aan de openbaring van God, maar omgekeerd God in zijn openbaring niet gebonden is aan de openbaringsgodsdienst. ${ }^{36}$

$\mathrm{Na}$ de Tweede Wereldoorlog schijnt Bavinck zich in stilzwijgen gehuld te hebben. Kraemer, Verkuyl en Van Leeuwen namen met zoveel woorden afscheid van de term 'de absoluutheid van het christendom.' Maar in tegenstelling tot Van Leeuwen bleven Kraemer en Verkuyl wel vasthouden aan het begrip 'de absoluutheid van Gods openbaring in Jezus Christus.' Alleen Verkuyl attendeerde op de absoluutheidsaanspraken van Jezus Christus zelf die aan de claims van apostelen en evangelisten, en van christenen en kerken ten grondslag liggen.

\section{De eigenheid van het christendom}

De verschuiving die in de twintigste eeuw zich op dit vlak voordeed, kan afgelezen worden uit de ontwikkelingen bij de Christelijke encyclopedie van Kok te Kampen. Voor de eerste druk schreef de VU-hoogleraar Valentijn Hepp

34 Ibid., 86-98.

35 Arend Th. van Leeuwen, De absoluutheid van het christendom (Oosterhesselen ca. 1970), 9-13.

36 Karl Barth, Kirchliche Dogmatik, I/2 (Zürich 1945), 356-96. 
een artikel over 'de absoluutheid van het christendom. ${ }^{37}$ Hetzelfde deed ds. H.G. Groenewoud voor de tweede druk. ${ }^{38}$ Maar in de derde druk (2005) is dit lemma niet meer opgevoerd.

Vanaf de jaren zestig in de vorige eeuw ging het denken van Nederlandse protestanten diverse kanten op. Deels werd in het verlengde van de thematiek uit de periode 1913-1971 nagedacht, deels werd hiermee radicaal gebroken. Hier worden in vogelvlucht vier denkrichtingen genoemd die in het post-'de absoluutheid van het christendom'-tijdperk de weg willen wijzen. Deze kunnen wellicht onder het kopje 'de eigenheid van het christendom' worden samengebracht. Immers, zij die radicaal gebroken hebben met het absoluutheidsdenken, kunnen 'de eigenheid van het christendom' plaatsen naast en tegenover 'de eigenheid' van het hindoeïsme, het boeddhisme, de islam en andere niet-christelijke godsdiensten.

\subsection{Het onderscheidend criterium}

De aanspraken op absoluutheid hebben een subjectieve en objectieve kant. De subjectieve kant is helder verwoord door Chantepie: wat voor mij absoluut is, behoeft niet noodzakelijkerwijs voor iedereen absoluut te zijn. Andere protestantse auteurs gingen op zoek naar de objectieve dimensie. Zij zochten deze op dogmatisch, ethisch en historisch vlak.

Als systematisch denkende zendingsmensen dachten Kraemer en Verkuyl aan de openbaring van God in Christus als onderscheidend criterium. Zij relativeerden 'de absoluutheid van het christendom,' maar niet 'de absoluutheid van de openbaring van God in Jezus Christus.' Anderen zochten dit criterium op ethisch vlak. Hidding is hiervan een duidelijk voorbeeld. Hij beschouwde het dubbele liefdegebod als het gegeven waardoor het christendom zich 'absoluut' onderscheidt van andere godsdiensten en geloven. Berkhof zocht het onderscheidend criterium in de geschiedenis: de verschijning van Jezus Christus op het toneel van de wereldgeschiedenis is een 'absoluut' novum. ${ }^{39}$ In vrije aansluiting bij Korff, Berkhof en Newbigin wees Jongeneel erop, dat Jezus en de eerste christelijke gemeente de in het Oude Testament voor het eerst omschreven lineaire geschiedbeschouwing (versus de toen gangbare cyclische opvatting) gemaakt hebben tot een beschouwing

37 Valentijn Hepp, “Absoluutheid van het christendom," in: Christelijke encyclopedie voor het Nederlandsche volk, I (Kampen 1925), 25.

38 H.G. Groenewoud, "Absoluutheid van het christendom," in: Christelijke encyclopedie, I (Kampen 1956), 56.

39 Hendrikus Berkhof, Christus, de zin van de geschiedenis (Nijkerk 1962). Ook in Engelse vertaling verschenen (1966). 
van universele betekenis. Immers, de islam, het humanisme, het communisme en de Verenigde Naties gingen zelfstandig verder op het joods-christelijke gedachtengoed. ${ }^{40}$ Met gebruikmaking van de aan de Duitse wijsgeer Karl Jaspers ontleende term 'axis' sprak hij over de 'axiale betekenis' van Jezus Christus in de wereldgeschiedenis. ${ }^{41}$

\subsection{Herijking van de term 'absoluutheid'}

Overigens zijn er moderne schrijvers die het begrip 'absoluutheid' herijken. Daartoe behoort in elk geval Emmanuel Levinas (1906-95) met zijn pleidooi voor 'de absoluutheid van de Ander' en 'het absolute gelaat van de Ander.'

Levinas liet sporen na in het Nederlandse protestantisme. In zijn inaugurale rede aan de Universiteit van Amsterdam (1981) gaf A.J. de Jong het denken van Levinas over 'absoluutheid' als volgt weer: "Het zedelijk appèl van de Ander [God] tast mijn vrijheid niet aan, want wij grenzen niet aan elkaar: wij zijn door een kloof van elkaar gescheiden; de Ander is absoluut ten opzichte van de totaliteit van mijn wereld. Met de absoluutheid van de Ander [God] hangt de radicaliteit van het gebod samen: het gebod is niet aangepast aan de mogelijkheden en de eisen van het moment en de situatie." 42

\subsection{Copernicaanse omwenteling - de niet-absoluutheid van het christen- dom}

In 1973 nam de Amerikaanse godsdienstwijsgeer John Hick (1922-2012) radicaal afscheid van het absoluutheidsdenken. Hij bepleitte een 'copernicaanse omwenteling' in kerk en theologie: onvoorwaardelijke acceptatie van het pluralisme. ${ }^{43}$

In Nederland was Leen den Besten, De absoluutheid van het christendom als filosofisch en theologisch probleem (1981), de eerste die deze omwenteling ter sprake bracht. Deze hervormde predikant (1946) die te Utrecht bij prof.dr.

40 Jan A.B. Jongeneel, Jesus Christ in world history: His presence and representation in cyclical and linear settings (Frankfurt am Main 2009), 379-88: "The axial significance of Jesus Christ." Vgl. J.E. Lesslie Newbigin, "The gathering up of history in Christ," in: Charles C. West - David M. Paton (red.), The missionary church in East and West (Londen 1959), 81-90.

41 Karl Jaspers, The origin and goal of history (New Haven 1959). Oorspronkelijk in het Duits verschenen (1949).

42 A.F. de Jong, Lossen en binden: Beschouwing over een gebruikswijze van de term 'absoluut' in het werk van Louis Althusser en Emmanuel Levinas (Amsterdam 1981), 15-18.

43 John Hick, God and the universe of faiths: Essyas in the philosophy of religion (Londen 1973), 120-32: "The Copernican revolution in theology." 
Jan M. van der Linde in de missiologie afgestudeerd was, gaf eerst een overzicht van het denken over 'absoluutheid' vóór Hegel, en daarna van dat van Hegel, Schleiermacher en Troeltsch. Vervolgens behandelde hij de 'exclusieve absoluutheid' bij Barth en de bezwaren daartegen van Kristensen en Hidding hier te lande, en die van Hick en andere pluralisten elders. Hierop liet hij een paragraaf volgen over 'de inclusieve absoluutheid' bij de rooms-katholieke theoloog Karl Rahner, met zijn fameuze uitspraak over 'het anonieme christendom.' De copernicaanse omwenteling bracht Den Besten op de gedachte de term 'absoluutheid' te laten vallen en te pleiten voor grotere openheid. In zijn woorden: "Het christelijk getuigenis is niet, dat geen enkele andere religie de mogelijkheid heeft om weg tot heil te zijn. De christen ervaart alleen de door het Bijbels kerygma verkondigde Christus als de weg tot heil. Het is voldoende te weten dat Christus de Weg [met hoofdletter] is." 44

De tweede Nederlandse auteur die inging op de copernicaanse omwenteling was de gereformeerde zendingstheoloog Pieter N. Holtrop te Kampen (1943-2012). Hij nam het initiatief tot publicatie van Voor Hem een ander? Ontwerpen voor een pluralistische theologie der religies (1990). Deze uitgave was een vertaling van enkele bijdragen uit de door John Hick en Paul F. Knitter geredigeerde bundel The myth of Christian uniqueness: Toward a pluralistic theology of religions (1987). Hierin stond een artikel van Hick over 'the non-absoluteness of Christianity,' dat door Holtrop niet werd opgenomen in de door hem geredigeerde bundel. ${ }^{45}$ In de Inleiding tot deze uitgave noemde Holtrop wel Kraemer, maar verwees hij niet naar Den Besten. Holtrop besloot zijn Inleiding met de opmerking dat christenen Jezus Christus blijven zien als "de unieke toegangsweg tot God," maar hun ogen niet moeten sluiten voor "de eigen waarheid, genade, heil en vreugde die in andere religieuze tradities liggen opgetast." 46

\subsection{Op zoek naar alternatieve termen}

Een reactie op de bundel The myth of Christian uniqueness kon niet uitblijven. Drie jaar later verscheen de bundel Christian uniqueness reconsidered, met bij-

44 Leen den Besten, De absoluutheid van het christendom als filosofisch en theologisch probleem (Woerden 1981), 83.

45 John Hick, "The non-absoluteness of Christianity," in: John Hick - Paul F. Knitter (red.), The myth of Christian uniqueness: Toward a pluralistic theology of religions (Maryknoll 1987), 28.

46 Pieter N. Holtrop, “Inleiding," in: Pieter N. Holtrop - Lourens Minnema (red.), Voor Hem een ander? Ontwerpen voor een pluralistische theologie der religies ('s-Gravenhage 1990), 18-19. 
dragen van onder meer de Duitse systematisch theologen Jürgen Moltmann en Wolfhart Pannenberg, en de Engelsman J.E. Lesslie Newbigin, met jarenlange zendingservaring in India. ${ }^{47}$ Beide bundels stelden de term 'uniqueness' centraler dan de term 'absoluteness.' Aan geen van beide bundels leverden Nederlandse protestanten een bijdrage. Hier te lande kreeg de eerstgenoemde bundel, door toedoen van Holtrop, meer aandacht dan de tweede. Zelfs het handboek van de theologen Van den Brink-Van der Kooi, Christelijke dogmatiek (2012), gaat aan Christian uniqueness reconsidered voorbij. ${ }^{48}$

Te Bazel verdedigde de Indiase theoloog Origin V. Jathanna zijn proefschrift over Kraemer en drie andere missionaire denkers: The decisiveness of the Christ-event and the universality of Christianity in a world of religious plurality (1981). ${ }^{49}$ Daarin gaf hij blijk de termen 'beslistheid' en 'universaliteit' te prefereren boven 'absoluutheid' en 'uniekheid.' Ook in Nederland gingen protestanten op zoek naar alternatieven. De termen 'normativiteit' en 'oorspronkelijkheid' werden geïntroduceerd, maar voorzover bekend niet gebruikt in de titels van monografieën en andere publicaties. In vrije aansluiting bij de Wereldraad van Kerken/Berkhof vroeg Bernard van den Toren aandacht voor 'de finaliteit' van de christelijke traditie. ${ }^{50}$

\section{Slotopmerkingen}

Deze historisch-systematische bijdrage wordt besloten met twee generale opmerkingen over de 'claims' van christenen en niet-christenen. ${ }^{51}$

Ten eerste, de omvang en de intensiteit van de claims van het hindoeïsme, het boeddhisme, de islam, het secularisme en het communisme nemen na 1945 eerder toe dan af. Hiervan dienen wij ons in Nederland ten volle bewust te zijn. Hierom waarschuwde de Amsterdamse godsdiensthistoricus C. Jouco Bleeker het Nederlandse protestantisme niet naïef te zijn en zich te hoeden voor een relativering van het evangelie: "De absolute waarheid van het

47 Gavin D'Costa (red.), Christian uniqueness reconsidered: The myth of a pluralistic theology of religions (Maryknoll 1990).

48 Gijsbert van den Brink - Cornelis van der Kooi, Christelijke dogmatiek: Een inleiding (Zoetermeer 2012).

49 Origen V. Jathanna, The Decisiveness of the Christ-Event and the Universality of Christianity in a World of Plurality: With special references to Hendrik Kraemer and Alfred George Hogg as well as to William Ernest Hocking and Pandipeddi Chenchiah (Bern 1981).

50 Bernard van den Toren, Breuk en brug: In gesprek met Karl Barth en postmoderne theologie over geloofsverantwoording (Zoetermeer 1995), 292-94.

51 George R. Sumner, The first and the last: The claims of Jesus Christ and the claims of other religious traditions (Grand Rapids 2004). 
Evangelie laat zich niet aanpassen aan de relativiteit van het samenleven der mensen." ${ }^{2}$ Ook wanneer wij besluiten de idealistische term 'absoluutheid' niet meer te gebruiken, blijven wij volledige verantwoordelijkheid dragen voor het vertolken van 'de claim' van Jezus Christus, niet alleen in de ontmoeting met het relativisme en het secularisme, maar ook in de omgang met de niet-christelijke godsdiensten.

Ten tweede, van alle in deze bijdrage genoemde personen was Verkuyl de enige die klip-en-klaar de absoluutheidsaanspraken van christenen en kerken herleidde tot de door Jezus zelf uitgesproken 'absolute' waarheidsclaim. In alomvattendheid overtreft diens claim die van alle andere stichters van godsdiensten, wereld- en levensbeschouwingen en ideologieën. Immers, alleen Jezus Christus claimt: "Mij is gegeven alle macht in hemel en op aarde" (Matthéüs 28:16-20). Hij is "de alfa en omega" (Openbaring 1:8). Meer dan ooit putten de vervolgde christenen nu kracht uit deze proclamatie, en moed om niet te capituleren voor de claims van hun onderdrukkers.

${ }^{*}$ Dit artikel is een uitwerking van het literatuuroverzicht gegeven door Jan A.B. Jongeneel, Nederlandse zendingsgeschiedenis: II: Ontmoeting van protestantse christenen met andere godsdiensten en geloven (1917-2017) (Utrecht 2018), 638-39.

J.A.B. Jongeneel is honorair emeritus hoogleraar missiologie van de Universiteit Utrecht. 